\title{
Does the SDR Have a Future?
}

\section{Citation}

Cooper, Richard N. 2010. "Does the SDR Have a Future?" Journal of Globalization and Development 1 (2) (January 27). doi:10.2202/1948-1837.1114.

\section{Published Version}

doi:http://dx.doi.org/10.2202/1948-1837.1114

\section{Permanent link}

http://nrs.harvard.edu/urn-3:HUL.InstRepos:13578516

\section{Terms of Use}

This article was downloaded from Harvard University's DASH repository, and is made available under the terms and conditions applicable to Open Access Policy Articles, as set forth at http:// nrs.harvard.edu/urn-3:HUL.InstRepos:dash.current.terms-of-use\#OAP

\section{Share Your Story}

The Harvard community has made this article openly available.

Please share how this access benefits you. Submit a story.

Accessibility 
July 2010

\title{
Does the SDR Have a Future?
}

\author{
Richard N. Cooper \\ Harvard University
}

This article will briefly address the future prospects for the dollar as an internationally acceptable denomination for assets, and then discuss the several ways in which the SDR or some other internationally-agreed reserve asset might partially substitute for the US dollar in its international roles, and even eventually replace it. It concludes that there is no practical substitute for the dollar in the near future, meaning the next decade or two; and that while the SDR could be made a substitute for the dollar along several dimensions in the longer run, it would require a major concerted effort by the leading governments of the world to do so.

It is worth recalling that the US dollar is not the world's key currency by policy design, just as English is not the leading global language by policy design. Both are the evolutionary outcomes of practice and experience. It would take both a major shock to the dollar and a viable alternative to dislodge it from widespread use. Like a common language, it enjoys "network externalities" - the greater the number of agents who use and accept it, the more useful it is to everyone, and the more entrenched it becomes. The dollar also enjoys a large market in low-risk and highly liquid securities, in the form of US Treasury bills; the liquidity both enhances and is enhanced by the network externalities. Over 80 percent of the world's foreign exchange transactions directly 
involve the US dollar. It is easy to hold and easy to use, even on a large scale. In short, it is highly convenient.

Are there other currencies that could substitute for the dollar in its international role? The obvious candidate is the euro, and indeed the euro already accounts for a significant and growing fraction of official international reserves. But despite great progress over the decade of its existence, the euro capital market is still quite fragmented, with varying degrees of liquidity depending on the security. Holders of international reserves cannot hold euros; they have to hold euro-denominated securities, and exactly what security it is makes a great deal of difference. The most prevalent eurodenominated government securities are those issued by the Italian government, with $\$ 2.0$ trillion outstanding at the end of 2009. Many central banks would hesitate to hold such securities, since Italian public debt exceeds GDP and the Italian government is not known for budgetary discipline or efficiency. German government debt outstanding was $\$ 1.55$ trillion. But until recently Germany has had an aversion to short-term debt, so only $\$ 458$ billion of this had a maturity under one year. Moreover, German buyers tend to hold to maturity, so the secondary market is much less well developed than it is in the United States, and German bonds are correspondingly less liquid, although liquidity can be achieved through the use of swaps. France had slightly more at $\$ 1.69$ trillion, followed by Spain as a distant fourth at $\$ 0.6$ trillion. So while in total there is much outstanding euro-denominated public debt, the market is more fragmented and much less liquid especially for large transactions - than the market in US government securities, which by December 2009 totaled $\$ 9.5$ trillion, of which $\$ 2.5$ trillion was short term. 
The market is better developed in the United Kingdom, but the amount of pounddenominated government debt at $\$ 1.1$ trillion was significantly smaller than that of the larger continental countries, and only ten percent was short-term. Canada's public debt was $\$ 0.9$ trillion, and Australia’s a mere $\$ 0.2$ trillion, although Russia has expressed interest in both countries.

Japan had extensive government debt, at $\$ 9.7$ trillion in December 2009 even more than the United States, and $\$ 2.5$ trillion was short-term. There are three potential problems with Japanese securities as a basis for an international currency. First, the yield has been exceptionally low, below one percent on short-term securities, during most of the past two decades. Second, while Japan has a relatively free market in public debt, Japan has a strong tradition of "guidance" by the Ministry of Finance, and that tradition has not entirely vanished. Foreigners might worry about new guidance that would limit their freedom of action and even discriminate against foreigners in favor of domestic holders. Third, among rich countries Japan has the highest ratio of debt to GDP, well over 100 percent. This does not pose a financing problem with high domestic saving and interest rates as low as they have recently been, but it might do so in the future, particularly in view of the rapid ageing of Japanese society (on which more below).

China had almost as much government debt outstanding as Germany, $\$ 1.46$ trillion, half of it short term. China's fiscal policy has been conservative, and the ratio of debt to GDP is moderate. But the Chinese capital market, including that for government securities, is not well developed; most purchasers hold until maturity. Foreigners at present do not have access to Chinese government securities, and the Chinese currency is not convertible for capital account transactions. Thus the yuan is not suitable for being 
an international currency at present. All that could change in the next two decades. Indeed, among the many objectives of China's government are a much improved capital market and a fully convertible currency. But China's financial system requires many improvements before these objectives can be securely achieved, and they are not likely to take place quickly.

I conclude that essentially on technical (market) grounds none of the other leading currencies in the world today is ready to replace the US dollar in its international role. The international role of the euro is likely to increase in the coming decade as noneuroland members of the European Union and aspiring candidates to the EU increasingly use euros in their transactions with euroland countries, for invoicing, for payment, and for holding international balances. Other countries closely linked economically to Europe are likely to do the same. But this increasing use of the euro is not likely to displace the dollar at the global level. In a growing world economy, there is room for the euro to increase its share in reserve holdings even while the value of dollar holdings continues to rise.

Moreover, on current benign projections for the world economy the GDP shares of Europe and of Japan are likely to fall significantly over the next two decades, largely for demographic reasons. Both parts of the world have low birth rates and are ageing rapidly. The share of the United States, in contrast, will decline only modestly, due to higher birth rates and continued significant immigration, while those of China and other developing countries grow significantly. Thus the relative importance of Europe and of Japan as trading destinations will gradually decline as that of successful developing 
countries increases, while the United States continues to be far the largest national economy, with only slight decline in share of gross world product.

For all these reasons, the dollar is not likely to be seriously displaced, so long as the United States continues to manage its monetary and fiscal affairs in a reasonable fashion, and so long as the US capital market remains open.

But will not holders of dollars lose value over time, as is frequently claimed, sometimes with anxiety? This question is more complicated than it at first appears, but the most likely answer is: not meaningfully. There are three different senses in which dollar reserves can "lose value": 1) against home currency; 2) against other currencies; and 3) in terms of goods and services available on the world market.

A "loss" in the value of dollar reserves occurs if the home currency (e.g. the Chinese yuan) appreciates against the dollar: the value of dollar reserves declines when measured in home currency, and the books of the monetary authority, measured conventionally in domestic currency, will show a loss on its holdings of foreign exchange reserves. But this loss arises only because of an accounting convention which should not in fact be applied to central banks. If they hold uncovered foreign exchange, that presumably reflects a deliberate (and often sensible) decision to have mismatched assets and liabilities because of the potential usefulness of the assets. It is therefore misguided to lament "losses" if the home currency appreciates. (The same logic would imply boasting gains when the home currency depreciates, which is much more common; but of course such gains are only meaningless accounting gains, without increasing the public's well-being at all.) 
If the dollar depreciates against the euro or other foreign currencies, it is of course true that the value of reserves measured in euros has declined, i.e. a "loss" has been incurred. The logic of this argument is that foreign exchange reserves always lose value unless they are held at all times in the currency that appreciates the most. It would also apply to reserve holdings in currencies other than the dollar. But central banks are not supposed to be currency speculators, and if they do speculate in currencies the wrath of the international community should come down on them. They have access to privileged information from other central banks and from institutions such as the Bank for International Settlements and the International Monetary Fund. They are thus potential inside traders with government backing that do not have to meet a market test.

The real concern should be whether reserves lose purchasing power over goods and services in the world market, since smoothing such purchases under various notalways-foreseen contingencies is presumably a principal reason for holding reserves. (Of course, if a country is concerned with value in terms of a particular commodity, such as oil, rather than general purchasing power, it should stock that particular commodity - as some countries do - rather than build foreign exchange reserves.) Here however it is important to recall that foreign exchange reserves are typically held in short-term interestbearing securities. If inflation rises seriously in a particular currency, its interest rate will also rise, so the holder will be compensated for the decline in purchasing power. Only surprise inflations therefore erode purchasing power, and the erosion is not likely to be great for short-term securities.

What about the other possibility, displacing the US dollar in its international role by a synthetic currency, as a matter of conscious and deliberate collective action? This 
possibility, quietly suggested by Governor Zhou of China's central bank in March 2009, could be achieved by substantially augmenting the role of the SDR, a synthetic unit account of the International Monetary Fund defined in terms of four currencies: the USD, the euro, the Japanese yen, and the British pound. What is not generally known is that such a move has been an official objective of the international community since 1978 . The second amendment to the IMF's Articles of Agreement states that members shall conduct their policies with respect to reserve assets consistent with "the objectives of promoting better international surveillance of international liquidity and making the special drawing right [SDR] the principal reserve asset in the international monetary system" (Article VIII.7).

The issues here are conceptual, practical, and even esthetic.

The conceptual issues concern the net gains that may be expected to accrue to the world at large from creating a new, man-made international currency, compared with the current non-systematic practices, relying on the US dollar and to a less extent on other currencies. These net gains are not completely obvious. Moreover, most of them would not occur without other important changes in how the international financial system functions, including international engagement in the role of national exchange rate policies to reduce volatility in movements among the major currencies which are components of the SDR. Such changes would be even more controversial than achieving wide acceptance of a synthetic international currency.

The esthetic issue concerns largely the offense that some observers take at having a national currency play the leading international role: it creates an asymmetry in a system which at least formally and legally (as in the United Nations Charter and most 
other international treaties) treats all nations as equal. It also appears to give the nation whose currency is used special privileges, although this too is not at all obvious on close inspection.

Most of the issues are practical, in principle solvable, but with difficulty and with undesirable and perhaps unacceptable side effects. One practical matter concerns the principles that would govern issuance of the synthetic currency, including who exactly would decide. SDR creation under existing IMF arrangements involves a quinquennial evaluation of whether the world economy needs additional liquidity, and a decision by IMF governors (essentially the finance ministers of the world) by an 85 percent weighted vote (which gives the European Union taken together and the USA power to block such a decision) concerning when and how much. Only two successful issuances had been decided before 2009, in 1969 and 1978, for a total of SDR 22 billion (about \$35 billion). A third, involving distribution to new members such as China and Russia, plus a new allocation in 2009, added \$283 billion. Most transactions in SDRs in fact have been between national monetary authorities and the IMF itself. This decision-making arrangement for creation is inappropriately cumbersome and time-consuming if the SDR is to become a true international currency. But who then should decide, and by what criteria? Moreover, the use of SDRs (through the IMF) takes several days, when often central banks need to decide to intervene in foreign exchange markets within hours; hence working balances in dollars or euros would still need to be held.

SDRs as currently constituted can be used only by national monetary authorities, the IMF, and selected designated financial institutions such as the World Bank and the Bank for International Settlements. Most holdings of US dollars outside the United 
States are by private parties, and financial markets are operated by and largely for private parties, with governments and central banks taking advantage of them. If the SDR were to become a truly international currency, it would have to be made accessible to private parties; or else the modus operandi of international financial relations would have to be radically revised, giving monetary authorities a much more central role in running financial markets. The current restriction applies only to holdings of and payments in SDRs. There is nothing that prevents private agents today from using the SDR as a unit of account in their transactions with foreigners. The SDR is priced in terms of convertible currencies, so there is no ambiguity about its value at any moment. That it is not used widely suggests either that inertia in human behavior is very high, however irrational that may be, or else that transactors see no compelling reason to shift to SDRs from dollars or whatever currency they may currently be using.

A third practical issue concerns what is to become of all the US dollars (and euros) that are held today in both private and official balances if the SDR (or some other synthetic unit) is to replace current reserve currencies. One approach would be to leave them, and substitute SDRs through incremental growth, such that the US dollar (and other national currencies now held abroad) would gradually recede in relative importance, without any formal displacement. Given the amount of foreign balances held today (over $\$ 6$ trillion in official reserves alone, and perhaps six times that in private balances), such an approach would take a very long time for the SDR to become the predominant reserve asset - and perhaps never in private balances, unless the process were forced in some way. An alternative approach would involve the creation of a "substitution account", whereby at least official holders and perhaps even private holders of dollars and other 
currencies would exchange their holdings for an equivalent value of SDRs. The question then arises what would become of the dollars and other national currencies received in this arrangement, e.g. by the International Monetary Fund or by a new institution created for the purpose. Should they sit there forever, or be amotized over time - implying a need, on this account, for the United States to run a currency account surplus. And would the obligors promise to maintain their SDR value? The United States and European governments might be expected to give exchange rate guarantees. But no Congress would provide an unconditional guarantee of value for assets which, though issued by the US government, were issued in US dollars and voluntarily acquired by foreign parties, even in some circumstances against the wishes of the United States.

To identify the practical issues that would have to be resolved in creating a synthetic international currency is useful, since it suggests that the gains from such a move would have to be sufficiently substantial to drive governments to try to solve the practical problems.

But so long as the dollar is widely accepted, will not the United States fiercely resist a move to an SDR-based system, because of the frequently vaunted gains that arise for the issuing country of a reserve currency? This is not the occasion for a lengthy discussion of the costs and benefits of an international currency for the issuing country, except to note that these are not nearly as great as is often implied. McKinsey Global Institute has recently provided a cost-benefit analysis for the United States, and concludes that the net gains in a normal year amount to $\$ 40-70$ billion, $0.3-0.5$ percent of GDP; and that in a year of financial stress the gains are likely to be smaller, even perhaps negative. This analysis focuses on three components: seigniorage, the gain that arises from issuing 
non-interest-bearing currency that is widely held abroad; lower interest rates, especially on government debt, that arise from international holdings of government securities; and the loss of export competitiveness that arises from higher-than-otherwise demand for the national currency. The first two are reckoned as benefits to the United States, the third as a cost, and of course the net effect depends precisely on the quantitative estimates for each effect. I believe MGI overstates the impact on US interest rates, given the increasing integration of the world capital market and its tendency to reallocate funds through arbitrage to higher-yielding assets; thus the net gains, already low in normal years on the MGI estimate, may be lower still.

As suggested, to substitute the SDR fully for the dollar in its international roles would be extremely ambitious. But the SDR could play a more modest role. Countries have built their foreign exchange reserves greatly during the course of the past decade, particularly following the Asian financial crisis of 1997-98. Reserves in developing countries and economies in transition grew from SDR 0.9 trillion in 2000 to SDR 2.5 trillion by the end of 2007. The increase was SDR 800 billion, 11 percent a year, even if China is excluded. Perhaps surprisingly, this rapid growth of reserves barely kept ahead of the growth of imports into these countries over the same period. A country can build its reserves (beyond interest earnings) only through running a surplus on exports of goods and services, or by importing capital, or both. Many developing countries learned during the financial crisis to be wary of reliance on imports of foreign private capital, so they have run current account surpluses - which of course must have their counterpart in current account deficits elsewhere, contributing to "global imbalances." 
The SDR was created in the late 1960s to satisfy increasing demand for reserves in a growing world economy, but in fact until 2009 the issuance of SDRs has been extremely modest, such that by the end of 2007 they accounted for less than one percent of total official reserves (not counting gold, which would lower the ratio further). In future the SDR could be created on a regular and substantial basis, enough approximately to satisfy the growing demand for reserves, perhaps $\$ 200$ billion a year or even more. Such a move would involve a political decision to use a mechanism we already have, and would not involve further amendments to the IMF Articles. The advantage is that it would reduce the pressure many countries evidently feel to earn additional reserves. Their demand would be satisfied by issuing new SDRs, and their drive to export would be correspondingly diminished. This in turn would lead to some reduction in current account deficits around the world, notably of the United States. It would also permit countries to use more of their domestic savings for investment at home instead of placing them in low-yield foreign exchange reserves.

It should not be supposed that the large global imbalances are due solely or even mainly to this factor; differences in demographic trends leading to differences in national saving and investment rates also play a important role, and most of the capital flows in recent years have been private, not lending to the reserve currency countries by countries building their official reserves. But it is one factor, and issuing SDRs on a regular basis could help reduce that source of imbalance.

Would the issuance of SDRs on a significant scale be inflationary, as some fear? That depends on the world's response to such issuance, and in particular the response in the reserve currency countries. Reducing the need to export and reducing trade surpluses 
in reserve-building countries would permit those countries to import more. This increase in import demand would increase export demand directly or indirectly in the reservecurrency countries, and in that sense would increase expansionary pressures in those countries. If the expansion were not desired, i.e. if those countries were operating near full employment and experiencing inflationary pressures, they could respond by contracting monetary and/or fiscal policies. Both the United States and the European Union have, by world standards, good records in responding to inflationary pressures for domestic reasons, i.e. without regard to their official reserves. So very likely any modest inflationary pressures that might arise from issuance of SDRs would be effectively neutralized by policy responses in the reserve-currency areas.

Such a move to create more SDRs would indeed partially substitute for the dollar as a reserve currency; that would be part of its purpose. But total foreign exchange reserves are so large relative to the indicated new issuance that the dollar would remain the dominant international currency, even in official reserves, for many years to come.

A more ambitious proposal, which would require amendment of the IMF Articles, would authorize the IMF to issue SDRs in abundance during global financial crises such as that experienced in 2008, with the clear understanding that these SDRs would be withdrawn after the world financial system returned to normal. Such an evolution of the role of the SDR might be a stepping stone toward its eventual private use, but for reasons given that event, if it occurs at all, is likely to be far in the future. 